\title{
Measuring Indonesia's Halal Tourism Development Using GMTI (A Case Study in West Sumatra)
}

\author{
Muh. Nashirudin ${ }^{1}$, Helmi Haris ${ }^{2}$, Zakky Fahma Auliya ${ }^{3}$, Agung Novianto Margarena ${ }^{4}$ \\ IAIN Surakarta, Jl. Pandawa, Pucangan, Kartasura, Sukoharjo, \\ Central Java, Indonesia (0271) 781516 \\ Universitas Sebelas Maret, Jl. Ir. Sutami 36A, Kentingan, Surakarta, \\ Central Java, Indonesia (0271) 647481 \\ \{muh.nashirudin@gmail.com ${ }^{1}$,helmi.solo@gmail.com², zakkyfahma@gmail.com³, \\ margarenaagung@student.uns.ac.id $\left.{ }^{4}\right\}$
}

\begin{abstract}
This study aims to measure the real readiness of the development of halal tourism in Indonesia. There were different views of the awards received by the two regions in Indonesia at The World Halal Tourism Award 2016 which were decided based on the polling, not based on the real conditions of halal tourism. The present study used the GMTI with four indicators namely access, telecommunications network, environment, and services in measuring tourist responses toward their interests in visiting West Sumatra. This research used quantitative methods and the samples were taken by purposive sampling with a sample of 50 non-local Muslim tourist respondents who have previously visited West Sumatra. The data were analyzed using simple linear regression employing SPSS ver. 21. The findings of the present study showed that the four GMTI indicators have significant effects on the intention of Muslim tourists in visiting West Sumatra.
\end{abstract}

Keywords: Halal Tourism, Access, Telecommunications Network, Environment, Services

\section{Introduction}

Foreign tourist arrivals in Indonesia experiences a significant increase from year to year, as of April 2018, there were 1.30 million visits. This number increased by $11.04 \%$ compared to April in the previous year (Y.o.Y) [1]. The most number of foreign tourists visiting Indonesia are Malaysia, China, Singapore, Timor-Leste, and Australia [2]. The level of global Muslim travel spend hits USD 142 billion (excluding Umrah \& Hajj), second to the Chinese market of USD 160 billion [3]. This market comes from Muslims in Southeast Asia, the Middle East (Qatar, UAE, Kuwait, Saudi Arabia, Oman, and others), Europe, Central Asia, and China [4].

High Muslim population growth makes the halal tourism industry interesting to study [5]. In 2018, global Muslim travel hit 140 million people, increased by $10 \%$ compared to 2017 of 131 million people with Indonesia as the top Muslim-visitor destination [6]. Thus, some Muslim-minority countries such as Japan [7], Korea [8], Thailand [9]-[11], and the United States continue to develop halal tourism destinations [12]. 
Indonesia as the largest Muslim population in the world [13] makes the halal tourism market segment interesting to work on. This is reflected in previous studies discussing halal tourism in Indonesia conducted by Asih and Asih [14], Jaelani [15], and Prabowo, Rahman, Rahman, and Samah [16]. The development of West Nusa Tenggara and West Sumatra are some of the examples [17]. The most successful development of halal tourism is in West Nusa Tenggara as the World's Best Halal Honeymoon Destination. Novotel Lombok of West Nusa Tenggara as a halal-friendly hotel won the World's Best Halal Beach Resort, and West Sumatra won the Best Halal Tourism Destination [18].

The awards received by West Nusa Tenggara and West Sumatra were based on polling in the website of The World Halal Tourism Award 2016. It was not based on the real conditions of halal tourism in the area. This becomes a fundamental problem in investigating the readiness of the West Sumatra province in preparing its region as a sharia tourist destination. This study is remarkably different from the previous studies conducted by Battor and Ismail [19], Chew and Jahari [7], Chookaew, Chanin, Charatarawat, Sriprasert, and Nimpaya [20], and Jaelani [21] as in this article, the author uses GMTI to measure respondents' intention in visiting halal tourism in West Sumatra.

\subsection{Sharia Tourism Industry in Indonesia}

Halal tourism is the delivery of tourism products based on the Muslim lifestyle during holidays. In addition, sharia tourism is flexible, rational, simple, and balanced. It aims to motivate tourists to get happiness and blessings from Allah (God) [22].

Halal tourism, which is currently one of the travel trends in the world, increases the interest of researchers to discuss about. Previous researchers gave their views in terms of the potential and prospects of halal tourism [23], marketing patterns [14], challenges in developing halal tourism [24], and the trend of Muslim millennial traveler [12].

Halal tourism is developed on the basis of Muslim travelers' market demand to be comfortable while traveling, even Malaysia has branded its country as a halal tourist destination [25]. The motivation of Muslim travelers in choosing halal tourism is partly due to their self-motivation and obedience to Islamic teachings [26]-[28].

The development of halal tourism is one of the efforts to increase the Muslim's intention due to the dominance of modern tourism with a liberal style that causes the reluctance of conservative Muslim families to visit tourist attractions [9]. Thus, it requires a different tour package [29] to attract Muslim families. Even so, halal tourism is not necessarily only specifically for Muslim travelers [21]. According to Chookaew, Chanin, Charatarawat, Sriprasert, and Nimpay [11], there are eight factors for sharia tourism measurement standard in terms of administration and management for all travelers which can be a distinctive characteristic, namely:

a. Service to the traveler must be compatible with the principles of Muslims as a whole;

b. The guides and staff must have discipline and respect for the principles of Islam;

c. Manage all activities that do not conflict with Islamic principles;

d. The building must be in accordance with the principles of Islam;

e. The restaurant must follow international standards of halal services;

f. Transport services must have security protection system;

g. There are places available for all Muslim travelers to conduct religious activities;

h. Traveling to places that do not conflict with the principles of Islam.

The needs of Muslim travelers are divided into two major categories, the first is tangible (Islamic religious facilities and Halal food), the second is intangible (Islamic entertainment, 
Islamic dress codes, general Islamic morality, Islamic call for prayer) [30]. From the characteristics of halal tourism described [11], there are four important aspects that must be considered to support Halal tourism, namely Location, transportation, Halal food, and hotel.

\subsection{GMTI Indicators}

The Global Muslim Travel Index (GMTI) is an index issued by the MastercardCressentrating, a rating agency for world halal tourist destinations [31]. The indicators used by this institution can be briefly explained as follows:

a. Ease of access. Ease of access in the first GMTI indicator includes Visa issued by the government, availability of air transportation, and adequate infrastructure.

b. Telecommunication Network. The availability of the telecommunications network in the second GMTI indicator is the availability of communication facilities and digital facilities.

c. Environment. Environmental indicators in this GMTI include the culture in the community and the ease and security in accessing it, the favorable climate, and previous tourist visits.

d. Services. Service indicators in the GMTI index include the availability of Halal food and places to conduct religious activities as the core needs and hotel availability and the number of flights to locations as core services. In this last index, a unique experience as an attraction for tourists is also added, which might not be found elsewhere.

\section{Literature Review}

\subsection{Halal Tourism}

Although are many studies regarding Halal Tourism, however, studies relating halal tourism or Sharia tourism with the creative industries are still limited. For instance, a study conducted by Dauli, Shamain, and Belhaj [32] describe halal tourism as one of the products in the tourism industry which has received many positive and successful responses in several trials in Tikris, Algeria. Halal Tourism or as-Siyahah al-Halal provides various facilities for Muslim families who hold various stringent Sharia Islamic law such as hotels that do not provide alcoholic drinks; swimming pools, sports center, and health facilities that separate men and women; airlines that do not provide alcoholic drinks and Haram (unlawful) food; giving prayer call, providing Islamic study and entertainment programs, providing al-Qur'an in the chairs, and separate male and female tourists in the waiting room.

Another study conducted by Dauli and Sulaiman [33] explained that Halal tourism has become a very attractive commodity and shows a very significant increase in various countries, both Islamic and non-Islamic countries. This is in line with the results of surveys from various world survey agencies which predict that the number of tourists in 2020 will reach 1.7 billion with a turnover of approximately 1600 billion USD. This means that the tourism sector, including halal tourism, is one of the country's large sources of income.

Istiratijiyyah Taswiq as-Siyahah al-Halal Fi ad-Duwal al-Islamiyyah: Dirasah Halah Malizia that is written by Shafshaf explains the marketing strategy of halal tourism in Malaysia which combines the beauty of natural resources, the friendliness of the people, the modernization without conflicting with Islamic values, customs and culture. Hence, according to this paper, Malaysia managed to attract a lot of interest from tourists from the Arab Gulf countries and Arab countries in general. This is in line with the paper written by Shafaei and Mohamed [25]. 
Meanwhile, studies on the creative industry have also been widely carried out. The concept of creative industries has attracted the attention of economic researchers over the past two decades. There have been many studies focusing on its contributions to the economy, in particular its effects on unemployment, regional development, and the dynamics of urban areas [34].

In recent years, the role of innovation in the creative industry has been through in-depth investigation. Some experts believe that the existence of innovation in a company can be categorized as the creative industry [35]. On the other hand, some studies formulate the role of creative industries in their contribution to innovation in the wider economy where input from creative industries can be used as an innovation in other industries [36].

All in all, halal tourism is an impact that arises from the rapid development of the halal industry [37]. At the same time, halal tourism is also an answer to the phenomenon of increasing demand for commercial tourism with services according to Islamic law [38]. Religion and religiosity slowly affect tourism [39]. Thus, halal tourism has consequences for the procurement of products and services [40] as well as marketing strategies adhering to the Islamic values [41] or according to the principles of the Qur'an and Hadith [42]. Halal tourism has significantly contributed to Indonesia's economic growth in the midst of a slowing global economy and thus needs to be developed [21].

\subsection{Ease of Access}

Access plays an important role in tourism, especially halal tourism and is a factor driving tourists to revisit tourist attractions [43]. Australia is one country that is concerned with accessibility tourism and makes improvements in making tourists interested in visiting the country [44]. Some external factors that encourage tourists to visit are low transportation costs, prices, distance to travel, climate conditions, service quality, opportunities for shopping, the image of tourist attractions, restaurants and cafes, and accessibility [45]. One way to ease access to tourist attractions is the availability of transportation, where there is a two-way system of connections including the demand for transport and services provided by infrastructure (such as the existence of toll roads and adequate public land, air, and sea transport system) [46].

There are three barriers that must be overcome by the tourism industry related to accessibility, namely: physical access constraint, attitudinal barriers, and lack of information. Constraint to physical access is very crucial such as the inaccessibility of transportation and accommodation [47]. the availability of international and domestic airports to ease the access to halal tourism is one of the priorities [23].

Tourism and transportation are two closely related things [48]. Transportation is a basic condition that determines the sustainability of tourism in the future [49] and tourism experience [50]. Accessibility is anything that makes it easy for every tourist to reach his destination tourism related to transportation and its supporting facilities, including infrastructure [51] and visa-free [52]. Because the same-day visit with adequate transportation determines the attractiveness of the destination [53].

\subsection{Telecommunication Network}

Indonesia is one of the countries with high levels of mobile phone use and great connectivity expectations [54]. Hence, the telecommunication network availability is a consideration of visiting intention [52]. When tourists have previous experiences, the next 
visit appears as an expectation [55]. Thus, the telecommunication network availability and online platform support are some of the effective tools in promoting tourist destinations [56].

\subsection{Environment}

Security is included in the socio-economic environment [57], while the other environment is socio-cultural [58]. Religion promotes tourism through belief systems in pilgrimages and cultural affinity [59]. Cultural norms are considered as the best approach to identify the needs of Muslim travelers [60]. The need for security is important to consider for tourists [61]; [52]. An online review can direct a person's attitude or behavior through review valence [62]. Thus, preferences can influence decision making [63]; [64].

\subsection{Services}

Quality of service has a different meaning depending on the context of different theoretical assumptions [65]. In the context of this study, there are several religious attributes related to service, such as the availability of halal food, and the availability of places to conduct religious activities [30]; [66]. Halal food is a Qur'anic term that means permitted or lawful, while the opposite is unlawful food which means forbidden or violated the law [67]. Places of worship should be equipped with the Qibla marker [9]. Religious attributes are proven to affect the satisfaction of the Muslim travelers [68]. This is the basis for tourism development [69].

\subsection{Visit Intentions}

The visit intention results in the possibility of feelings generated in certain people, places, and periods [70]. The intention is what causes direct behavior in the form of a visit decision [71]; [72]. In the context of tourism, past experience can influence future visit decisions [73]. Tourists who get a positive perception on the first visit are more easily convinced to revisit [45].

\section{Hypothesis Formulation and Framework for Thinking}

\subsection{The Ease of Access to Visit Intention}

Basically, tourists will revisit the destinations that are easily accessible either through air, sea, or land transportation [74]. A study in Mauritius proffers that satisfaction with the airport services, including the availability of adequate air transportation has an impact on revisit intention [75]. A study conducted in Spain found that justice perceptions related to the availability of land transportation create a positive influence on revisit intention [53]. A study in Turkey found that accessibility and infrastructure affect the revisit intention [76]. In Taiwan, Muslim Friendly Tourism (MFT) is represented by visa-free, airport services, as well as the availability of air transportation that impacts the visit intentions [52].

$\mathrm{H}_{1}$ : Ease of access affects the intention of Muslim tourists visiting West Sumatra. 


\subsection{Telecommunication Network to Visit Intention}

Online platforms such as websites and social media help promote and build tourist destinations [56]. The ease of use of blogs affects the revisit intention [77]. A study shows that friendliness towards Muslim travelers is manifested in the ease of communication that impacts visit intention [52].

$\mathrm{H}_{2}$ : The telecommunication network affects the intention of Muslim tourists visiting West Sumatra.

\subsection{Environment to Visit Intention}

Security is one of the important things that tourists consider [61]. This is supported by a study conducted by Liu et al., (2018) in Taiwan which states that security supports visit intentions. Another study conducted in Thailand found that experience of the new culture would affect the visit intentions [73]. Another study in Thailand supports cultural activities that influence future visit intentions [78]. In India, the cognitive image represented by climate, culture, and security has an impact on travel intention [79]. Previous online reviews related to tourist destinations, hotels, and services became the next reference [80]. A study on Chinese tourists visiting Finland shows that the e-WOM (electronic word of mouth) influences visit intentions [81]. This is confirmed by a study conducted by Fakharyan [82]; Pietro and Pantano [83]; and Abubakar and Ilkan [84].

$\mathrm{H}_{3}$ : Environment affects the intention of Muslim tourists visiting West Sumatra.

\subsection{Services to Visit Intention}

Visitors need accommodation for a visit of more than one day [74]. A study in Kuwait yields a positive relationship between the availability of halal food services and places of worship on visit intention [45]. A study in Japan with Muslim tourist respondents found that the availability of halal facilities including hotels and restaurants affects revisit intention [85]. Another study in Korea stated that the availability of halal food had an effect on the Muslim traveler's revisit intention [86]. An impression of local food in Italy has an impact on revisit intention [87].

$\mathrm{H}_{4}$ : Services affect the intention of Muslim tourists visiting West Sumatra.

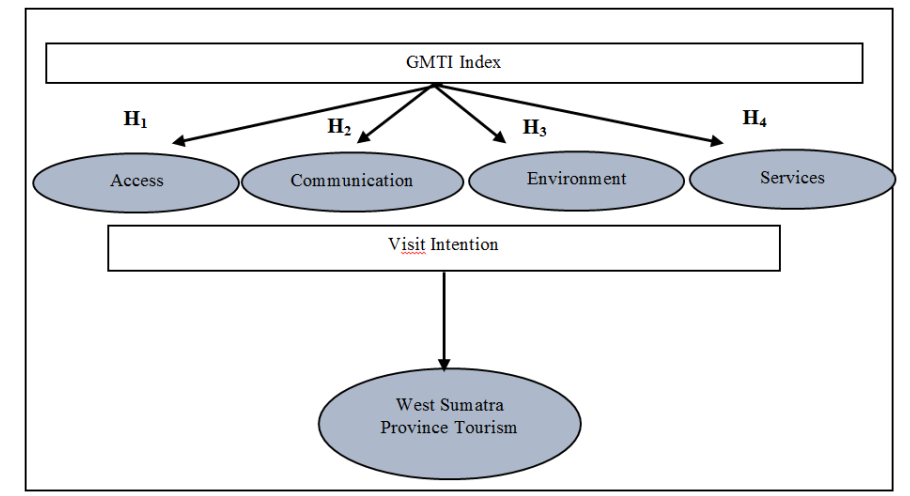

Fig. 1. Framework for Thinking 


\section{Method}

This study is quantitative research. The quantitative method in this study intends to collect, process, test, and analyze data in the form of numbers. This study aims to find out how GMTI indicators affect the tourist visit intention to West Sumatra.

The population is a general and certain area that has certain characteristics and quantities determined by researchers to be studied and then drawn conclusions [88]. The population in this study were all visitors in the tourist attraction in West Sumatra. The sample taken in this study was 50 respondents, assuming that the minimum sample in a multiple linear regression model was 30 respondents.

The sampling technique used in this study was the nonprobability sample, where the selection of population members used purposive sampling. The sample selection criteria includes:

a. Never visited a tourist attraction in West Sumatra, at least once.

b. Not a local resident of West Sumatra.

c. Muslim tourists.

In this study, the data was collected through questionnaires. Based on the relationship between variables, the variable is divided into two, namely the independent variable and the dependent variable. The variables in this study are:

a. Independent variable. The independent variable is the variable that influences or is the cause of the change or existence of the dependent variable. The independent variables in this study are Ease of Access $\left(\mathrm{X}_{1}\right)$, Telecommunication Networks $\left(\mathrm{X}_{2}\right)$, Environment $\left(\mathrm{X}_{3}\right)$, and Services $\left(\mathrm{X}_{3}\right)$.

b. Dependent Variable. The dependent variable is the variable that is affected or which is the result of the independent variable. The dependent variable of this research is visit intention (Y).

Table 1. Operational Definition of Variables

\begin{tabular}{|c|c|c|}
\hline Variables & Definition & Indicators \\
\hline Ease of Access $\left(\mathrm{X}_{1}\right)$ & $\begin{array}{l}\text { The ease of access refers to } \\
\text { how tourists can easily access } \\
\text { tourist attractions. }\end{array}$ & $\begin{array}{l}\text { a. The availability of air transport } \\
\text { facilities, } \\
\text { b. The availability of adequate } \\
\text { infrastructure }\end{array}$ \\
\hline $\begin{array}{l}\text { Telecommunication } \\
\text { Networks }\left(\mathrm{X}_{2}\right)\end{array}$ & $\begin{array}{l}\text { Availability of the required } \\
\text { telecommunication network. }\end{array}$ & $\begin{array}{l}\text { a. Availability of communication facilities } \\
\text { that ease tourists } \\
\text { b. Availability of digital facilities. }\end{array}$ \\
\hline Environment $\left(\mathrm{X}_{3}\right)$ & $\begin{array}{l}\text { The environment around the } \\
\text { tourist attractions }\end{array}$ & $\begin{array}{l}\text { a. Culture in society. } \\
\text { b. Ease and security in accessing it. } \\
\text { c. Supporting climate. } \\
\text { d. Previous tourist visits. }\end{array}$ \\
\hline Services $\left(\mathrm{X}_{4}\right)$ & Services in tourist attractions & $\begin{array}{l}\text { a. Availability of halal food } \\
\text { b. The availability of places of worship as } \\
\text { core needs. } \\
\text { c. The availability of hotel } \\
\text { d. The number of flights to the location as } \\
\text { core services. } \\
\text { e. The existence of a unique experience as } \\
\text { an attraction for tourists, which may not } \\
\text { be obtained elsewhere. }\end{array}$ \\
\hline
\end{tabular}




\begin{tabular}{llll}
\hline \multicolumn{2}{c}{ Variables } & \multicolumn{1}{c}{ Definition } & \multicolumn{1}{c}{ Indicators } \\
\hline Revisit & Intention & The tendency of someone to & a. The desire to find out \\
(Y) & stay in the subject to feel & b. Taking the time to learn more \\
& happy and interested in a & c. Preparing to visit \\
& particular field or thing & \\
\hline
\end{tabular}

\section{Results}

The t-test basically shows how far the influence of one independent variable individually in explaining the variation of the dependent variable. The null hypothesis $\left(\mathrm{H}_{0}\right)$ to be tested is whether a parameter (bi) is equal to zero. T-table can be calculated through the formula of ttable $=(\alpha / 2 ; n-k-1)$ where $\alpha$ used in the two-tailed test is $5 \%(\alpha=0,05))$ with $\mathrm{n}=47$; and $\mathrm{k}$ is an independent variable, so that the t-table of 1.678 can be obtained. T-test results are presented in Table 2:

Table 2. Results of Hypothesis Test (t-test)

\begin{tabular}{lccl}
\hline \multicolumn{1}{c}{ Variables } & $\mathbf{T}_{\text {count }}$ & Sig. & \multicolumn{1}{c}{ Description } \\
\hline Ease of Access $\left(\mathrm{X}_{1}\right)$ & 2.801 & 0.003 & There is an effect of ease of access to visit intention \\
Telecommunication & 2.684 & 0.002 & $\begin{array}{l}\text { There is an effect of telecommunication networks to } \\
\text { visit intention }\end{array}$ \\
Networks $\left(\mathrm{X}_{2}\right)$ & & & $\begin{array}{l}\text { There is an effect of the environment to visit intention } \\
\text { Environment }\left(\mathrm{X}_{3}\right)\end{array}$ \\
Services $\left(\mathrm{X}_{4}\right)$ & 3.171 & 0.000 & $\begin{array}{l}\text { Then } \\
\text { There is an effect of services to visit intention }\end{array}$ \\
\hline \multicolumn{3}{c}{ Source: Statistical Data Proceed, 2018 }
\end{tabular}

The t-count of the variable of ease of access is 2.801 which is greater than 1.678 with a significance value of $0.003(<0.05)$. Thus, $\mathrm{H}_{1}$ is accepted that the ease of access affects the visit intention. This is in line with a study conducted by Liu et al., [52] Stating that the ease of access described in the MFT through visa-free, infrastructure such as airports, and the availability of air transportation impact the visit intention. Hence, the West Sumatra government needs to improve the availability of infrastructure [51], transportation [53], and visa-free [52] to increase the interest in tourist visits. Basically, tourists will visit destinations that are easily accessible [74]. The t-count for the telecommunication network variable is 2.684 which is greater than 1.678 with a significance value of $0.002(<0.05)$. Thus, $\mathrm{H}_{2}$ is accepted that the telecommunications network affects visit intention. This is supported by a study conducted by Liu et al., [52] Milinillo et al., [56], and Chen et al., [77] stating that the telecommunication network affects visit intention. Hence, the West Sumatra government needs to improve telecommunications network in response to tourist expectations of the availability of telecommunications networks[52].

The t-count for the variable of environment is 3.171 which is greater than 1.678 , with a significance value of $0.000(<0.05)$. This shows that $\mathrm{H}_{3}$ is accepted that the environment affects visit intention. This is similar with a result yielded by Khan et al., [79] that the environment represented by climate, culture, and security affects travel intention. Thus, the government of West Sumatra is advised to improve the security [61] and cultural experience [78]. Since they are the reasons for tourist visit [73]. The t-count of services is 2.725 which is greater than 1.678 with a significance value of $0.001(<0.05)$. This shows that $\mathrm{H}_{4}$ is accepted that services affect visit intention. This is in line with what Nassar et al., [45] stating that the availability of halal food services and places of worship affect visit intention. Thus, the West Sumatra government needs to improve sharia-based services. These facilities include 
accommodation [85] because visitors will certainly need it when visiting more than one day [74], halal food that adheres to Islamic law [67], and places of worship with the Qibla markers [30].

\section{Conclusion}

This study aims to find out the effect of the indices in GMTI on the development of tourism in Padang, West Sumatra. The indices include ease of access, telecommunication networks, environment, and services. The following conclusions are drawn:

a. Testing the variable of ease of access. The t-test result shows that the t-count for the ease of access variable is 2.801 which is greater than 1.678. The significance value of 0.003 is smaller than 0.05 . Since the level of significance is less than $0.05, \mathrm{H}_{1}$ is accepted that ease of access affects the visit intention.

b. Testing the variable of telecommunication network. The t-count is 2.684 which is greater than 1.678 with a significance value of 0.002 or less than 0.05 . Since the level of significance is less than 0.05 , then, $\mathrm{H}_{2}$ is accepted that the telecommunication network affects visit intention.

c. Testing the variable of environment. The t-test results obtained is 3.171 , which is greater than 1.678 with a significance value of 0.000 or less than 0.05 . Because the level of significance is less than 0.05 , this shows that $\mathrm{H}_{3}$ is accepted that the environment affects visit intention.

d. Testing the variable of Services. Based on the t-test results obtained, the obtained t-count is 2.725 which is greater than 1.678 with a significance value of 0.001 (less than 0.05). Because the level of significance is less than 0.05 . This shows that $\mathrm{H}_{4}$ is accepted that services affect the visit intention.

\section{Limitation}

The independent variable used in this study affects $52.8 \%$ of the visit intention. There are still $47.2 \%$ of variables outside the GMTI that affect the interest of tourists visiting West Sumatra.

\section{References}

[1] Badan Pusat Statistik, "www.bps.go.id," 2018. https://www.bps.go.id/pressrelease/2018/06/04/1472/jumlah-kunjungan-wisman-keindonesia-april-2018-mencapai-1-30-juta-kunjungan--.html.

[2] H. Gusman, "Kunjungan Wisman: Malaysia Paling Banyak, Inggris Paling Royal Tirto.ID," tirto.id, 2019. .

[3] Thomson Reuter, "Strategic Roadmap for Development of Islamic Tourism in OIC Member Countries Statistical, Economic and Social Research and Training," no. July, pp. 4-7, 2017.

[4] Dinas Kebudayaan Pariwisata Sumatra Barat, "www.sumbarprov.go.id," 2016. https://www.sumbarprov.go.id/details/news/8114.

[5] M. Battour and M. N. Ismail, "The Role of Destination Attributes in Islamic Tourism," SHS Web Conf., vol. 12, p. 1077, 2014, doi: 10.1051/shsconf/20141201077. 
[6] Mastercard-CrescentRating, "Mastercard-CrescentRating Global Muslim Travel Index (GMTI) 2019: Indonesia and Malaysia Take the Top Positions in the Fast Growing Muslim Travel Market," Mastercard-CrescentRating, 2019.

[7] E. Y. T. Chew and S. A. Jahari, "Destination image as a mediator between perceived risks and revisit intention: A case of post-disaster Japan," Tour. Manag., vol. 40, pp. 382-393, 2014, doi: 10.1016/j.tourman.2013.07.008.

[8] M.-J. Kim, C.-K. Lee, and N. Chung, "Investigating the Role of Trust and Gender in Online Tourism Shopping in South Korea," J. Hosp. Tour. Res., vol. 37, no. 3, pp. 377-401, 2013, doi: 10.1177/1096348012436377.

[9] O. Chanin, P. Sriprasert, H. A. Rahman, and M. S. Don, "Guidelines on Halal Tourism Management in the Andaman Sea Coast of Thailand," J. Econ. Bus. Manag., vol. 3, no. 8, pp. 791-794, 2015, doi: 10.7763/joebm.2015.v3.287.

[10] L. M. Tsai, K. Sakulsinlapakorn, and T. Council, "Exploring Tourists' Push and Pull Travel Motivations to Participate in Songkran Festival in Thailand as a Tourist Destination: A Case of Taiwanese Visitors," J. Tour. Hosp. Manag., vol. 4, no. 5, pp. 183-197, 2016, doi: 10.17265/2328-2169/2016.10.001.

[11] S. Chookaew, O. chanin, J. Charatarawat, P. Sriprasert, and S. Nimpaya, "Increasing Halal Tourism Potential at Andaman Gulf in Thailand for Muslim Country," J. Econ. Bus. Manag., vol. 3, no. 7, pp. 739-741, 2015, doi: 10.7763/joebm.2015.v3.277.

[12] M. Shakona, K. Backman, S. Backman, W. Norman, Y. Luo, and L. Duffy, "Understanding the traveling behavior of Muslims in the United States," Int. J. Cult. Tour. Hosp. Res., vol. 9, no. 1, pp. 22-35, 2015, doi: 10.1108/IJCTHR-05-2014-0036.

[13] V. B. Kusnandar, "Indonesia, Negara dengan Penduduk Muslim Terbesar Dunia Databoks," databoks.katadata.co.id, 2018.

[14] S. Asih and S. Asih, "Marketing Strategy Implementation in Developing Sharia Tourism in Indonesia," Int. Proc. Econ. ..., vol. 84, pp. 133-137, 2015.

[15] A. Jaelani, "Islamic Tourism Development in Cirebon: The Study Heritage Tourism in Islamic Economic Perspective," MPRA Pap., no. 74833, 2016.

[16] S. Prabowo, A. A. Rahman, S. A. Rahman, and A. A. Samah, "Revealing factors hindering halal certification in East Kalimantan Indonesia," J. Islam. Mark. Vol., vol. 6, no. 2, pp. 268-291, 2015.

[17] A. Sapudin, F. Adi, and Sutomo., "Analisis Perbandingan Hotel dan Pariwisata Syariah dengan Konvensional,” Magister Manajemen Syariah IPB., Bogor, 2014.

[18] K. P. dan T. K. P. K. Biro Hukum dan Komunikasi Publik, "Kementerian Komunikasi dan Informatika," Kominfo, 2016. .

[19] M. Battour and M. N. Ismail, "Halal tourism: Concepts, practises, challenges and future," Tour. Manag. Perspect., vol. 19, pp. 150-154, 2016, doi: 10.1016/j.tmp.2015.12.008.

[20] S. Chookaew, O. Chanin, J. Charatarawat, P. Sriprasert, and S. Nimpaya, "Increasing Halal Tourism Potential at Andaman Gulf in," J. Econ. Bus. Manag., vol. 3, no. 7, 2015.

[21] A. Jaelani, "Halal tourism industry in Indonesia: Potential and prospects," Business, vol. 7, no. 76235, pp. 25-34, 2017, doi: 10.1227/01.NEU.0000349921.14519.2A.

[22] L. Munirah and H. N. Ismail, "Muslim Tourists' Typologi in Malaysia: Perspectives and Challenges," in Proceedings of the Tourism and Hospitality International Conference., 2012.

[23] A. Jaelani, "International Review of Management and Marketing Halal Tourism Industry in Indonesia: Potential and Prospects," Int. Rev. Manag. Mark., vol. 7, no. 3, 
pp. 25-34, 2017.

[24] N. K. Gabdrakhmanov, N. M. Biktimirov, M. V. Rozhko, and L. V. Khafizova, "Problems of development of halal tourism in Russia," J. Organ. Cult. Commun. Confl., vol. 20, no. Special Issue 2, pp. 88-93, 2016.

[25] F. Shafaei and B. Mohamed, "Malaysia's branding as an Islamic tourism hub: An assessment," Geogr. - Malaysian J. Soc. Sp., vol. 11, no. 1, pp. 97-106, 2015.

[26] M. M. Battour, M. M. Battor, and M. Ismail, "The mediating role of tourist satisfaction: A study of Muslim tourists in Malaysia," J. Travel Tour. Mark., vol. 29, no. 3, pp. 279-297, 2012, doi: 10.1080/10548408.2012.666174.

[27] K. M. Wong and G. Musa, "Retirement motivation among 'Malaysia my second home' participants," Tour. Manag., vol. 40, pp. 141-154, 2014, doi: 10.1016/j.tourman.2013.06.002.

[28] J. C. Henderson, "Sharia-compliant hotels," Tour. Hosp. Res., vol. 10, no. 3, pp. 246 254, 2010, doi: 10.1057/thr.2010.3.

[29] L. M. Kamarudin and H. N. Isamil, “"Muslim Tourism: The Tendency of Islamic Traveling Attributes from Malaysia Perspective," Int. Soc. Sci. Tour. Res. Conf. UNISZA, Teren. Malaysia, vol. 91, no. April, pp. 399-404, 2016.

[30] M. Battour, M. N. Ismail, and M. Battor, "The impact of destination attributes on Muslim tourist's choice," Int. J. Tour. Res., vol. 13, no. 6, pp. 527-540, 2011, doi: $10.1002 /$ jtr. 824 .

[31] Mastercard \& Crescentrating, "Mastercard-Crescentrating GMTI 2018 Global Muslim Travel Index 2018," no. April, p. 3, 2018, [Online]. Available: https://www.halalmedia.jp/wp-content/uploads/2018/04/GMITI-Report-2018.pdf.

[32] S. Dauli, A. B. Shamain, and Farraji Belhaj, "Tajarub Najihah fi Tikris Mafhum asSiyahah al-Halal,” Int. Islam. Mark. Assoc. J., vol. 5, no. 5, 2016.

[33] Su'ad Dauli and Ilyas Sulaiman, "As-Siyahah al-Halal Bain an-Nadzariyyah wa atTathbiq (tajarub Najihah li Daulah Ghair Islamiyyah 'Brithaniya,"” J. Al-Lughah al'Arabiyah, p. 34, 2016.

[34] R. Andari, H. Bakhshi, W. Hutton, A. O'Keeffe, and P. Schneider, Staying Ahead: The economic performance of the UK's Creative Industries. London: The Work Foundation, 2007.

[35] L. Green, I. Miles, and J. Rutter, Hidden Innovation in the Creative Industries. London: NESTA, 2007.

[36] H. Bakhshi, E. McVittie, and J. Simmie, Creating Innovation Do the Creative Industries Support Innovation in the Wider Economy? London: NESTA, 2008.

[37] Z. Samori, N. Z. Md Salleh, and M. M. Khalid, "Current trends on Halal tourism: Cases on selected Asian countries," Tour. Manag. Perspect., vol. 19, pp. 131-136, 2016, doi: 10.1016/j.tmp.2015.12.011.

[38] M. Carboni, C. Perelli, and G. Sistu, "Is Islamic tourism a viable option for Tunisian tourism? Insights from Djerba," Tour. Manag. Perspect., vol. 11, pp. 1-9, 2014, doi: 10.1016/j.tmp.2014.02.002.

[39] G. M. Ghani, "Tourist arrivals to Malaysia from Muslim countries," Tour. Manag. Perspect., vol. 20, pp. 1-9, 2016, doi: 10.1016/j.tmp.2016.06.003.

[40] S. Razzaq, C. M. Hall, and G. Prayag, "The capacity of New Zealand to accommodate the halal tourism market - Or not," Tour. Manag. Perspect., vol. 18, pp. 92-97, 2016, doi: 10.1016/j.tmp.2016.01.008.

[41] N. A. Othman and S. A Jamal, "Innovative System Indicators for Islamic Tourism Using C-PEST Factors," J. Tour. Hosp., vol. 6, no. 4, 2017, doi: 10.4172/2167- 
0269.1000298 .

[42] J. Jafari and N. Scott, "Muslim world and its tourisms," Ann. Tour. Res., vol. 44, no. 1, pp. 1-19, 2014, doi: 10.1016/j.annals.2013.08.011.

[43] M. N. Khuong and H. T. T. Ha, "The Influences of Push and Pull Factors on the International Leisure Tourists' Return Intention to Ho Chi Minh City, Vietnam - A Mediation Analysis of Destination Satisfaction," Int. J. Trade, Econ. Financ., vol. 5, no. 6, pp. 490-496, 2014, doi: 10.7763/ijtef.2014.v5.421.

[44] S. Darcy, SETTING A RESEARCH AGENDA FOR ACCESSIBLE TOURISM, 1st ed. CRC for Sustainable Tourism Pty Ltd, 2006.

[45] M. A. Nassar, M. M. Mostafa, and Y. Reisinger, "Factors influencing travel to Islamic destinations: An empirical analysis of Kuwaiti nationals," Int. J. Cult. Tour. Hosp. Res., vol. 9, no. 1, pp. 36-53, 2015, doi: 10.1108/IJCTHR-10-2014-0088.

[46] G. Toht and L. David, "The Connection Between Accessibility and Tourism," Delhi Bisuness Rev., vol. 11, no. 45, p. 39, 2010.

[47] V. Eichhorn and D. Buhalis, "Accessibility: A key objective for the tourism industry," Access. Tour. Concepts Issues, vol. 4, no. January, pp. 46-61, 2010, doi: 10.21832/9781845411626-006.

[48] Fundación ONCE, "Rights of Tourists with Disabilities in the European Union Framework," Eur. Netw. Access. Tour., no. December, 2008.

[49] G. Toth and L. David, "The Connection Between Accessbility and Tourism," Delhi Bus. Rev., vol. 11, no. 1, 2010.

[50] A. S. Tecau, G. Bratucu, B. Tescaşiu, I. B. Chiţu, C. P. Constantin, and D. Foris, "Responsible tourism-integrating families with disabled children in tourist destinations," Sustain., vol. 11, no. 16, pp. 1-18, 2019, doi: 10.3390/su11164420.

[51] S. Yacob, J. Johannes, and N. Qomariyah, "Does Destination Attractiveness and Destination Image Create Increase of Visiting Intention in Indonesia Rural Tourism?," Sriwij. Int. J. Dyn. Econ. Bus., vol. 3, no. 2, p. 122, 2019, doi: 10.29259/sijdeb.v3i2.122-133.

[52] Y.-C. Liu, I.-J. Li, S.-Y. Yen, and P. J. Sher, "What Makes Muslim Friendly Tourism? An Empirical Study on Destination Image, Tourist Attitude and Travel Intention," $A d v$. Manag. Appl. Econ., vol. 8, no. 5, pp. 1792-7552, 2018, doi: http://www.scienpress.com/Upload/AMAE\%2fVol\%208_5_3.pdf.

[53] P. Zoghbi-Manrique-de-Lara and R. M. Guerra-Báez, "Fairness in the local movements of tourists within a destination: justice perceptions, bus services, and destination loyalty," Int. J. Cult. Tour. Hosp. Res., vol. 10, no. 3, pp. 323-339, 2016, doi: 10.1108/IJCTHR-09-2015-0103.

[54] J. Li, P. L. Pearce, and D. Low, "Media representation of digital-free tourism: A critical discourse analysis," Tour. Manag., vol. 69, no. June, pp. 317-329, 2018, doi: 10.1016/j.tourman.2018.06.027.

[55] S. Campo-Martínez, J. B. Garau-Vadell, and M. P. Martínez-Ruiz, "Factors influencing repeat visits to a destination: The influence of group composition," Tour. Manag., vol. 31, no. 6, pp. 862-870, 2010, doi: 10.1016/j.tourman.2009.08.013.

[56] S. Molinillo, F. Liébana-Cabanillas, R. Anaya-Sánchez, and D. Buhalis, "DMO online platforms: Image and intention to visit," Tour. Manag., vol. 65, pp. 116-130, 2018, doi: 10.1016/j.tourman.2017.09.021.

[57] M. J. Khan, S. Chelliah, M. S. Haron, and S. Ahmed, "Role of travel motivations, perceived risks and travel constraints on destination image and visit intention in medical tourism: Theoretical model," Sultan Qaboos Univ. Med. J., vol. 17, no. 1, pp. 
e11-e17, 2017, doi: 10.18295/squmj.2016.17.01.003.

[58] H. Zamani-Farahani and G. Musa, "The relationship between Islamic religiosity and residents' perceptions of socio-cultural impacts of tourism in Iran: Case studies of Sare'in and Masooleh," Tour. Manag., vol. 33, no. 4, pp. 802-814, 2012, doi: 10.1016/j.tourman.2011.09.003.

[59] D. N. Balaam and B. Dillman, Introduction to international political economy., 7th ed. Routledge, 2015.

[60] H. Oktadiana, P. L. Pearce, and K. Chon, “Muslim travellers' needs: What don't we know?," Tour. Manag. Perspect., vol. 20, pp. 124-130, 2016, doi: 10.1016/j.tmp.2016.08.004.

[61] A. Tyagi, R. L. Dhar, and J. Sharma, "Police culture, tourists and destinations: A study of Uttarakhand, India," Tour. Manag., vol. 52, pp. 563-573, 2016, doi: 10.1016/j.tourman.2015.08.008.

[62] T. Reimer and M. Benkenstein, "When good WOM hurts and bad WOM gains: The effect of untrustworthy online reviews," J. Bus. Res., vol. 69, no. 12, pp. 5993-6001, 2016, doi: 10.1016/j.jbusres.2016.05.014.

[63] F. Abdullah, Z. Abdurahman, and J. Hamali, "Managing Customer Preference for the Foodservice Industry," Int. J. Innov. Manag. Technol., vol. 2, no. 6, pp. 525-533, 2011.

[64] D. Yüncü, "Relationships between perceptions of virtual destination environment, satisfaction and loyalty," J. Hosp. Tour. Technol., vol. 6, no. 2, pp. 160-173, 2015, doi: 10.1108/JHTT-07-2014-0021.

[65] J. H. Lee, H. D. Kim, Y. J. Ko, and M. Sagas, "The influence of service quality on satisfaction and intention: A gender segmentation strategy," Sport Manag. Rev., vol. 14, no. 1, pp. 54-63, 2011, doi: 10.1016/j.smr.2010.02.002.

[66] I. S. Suid, N. A. M. Nor, and H. Omar, "A Review on Islamic Tourism and the Practical of Islamic Attributes of Destination in Tourism Business," Int. J. Acad. Res. Bus. Soc. Sci., vol. 7, no. 12, pp. 255-269, 2018, doi: 10.6007/ijarbss/v7-i12/3609.

[67] M. Tieman and F. H. Hassan, "Convergence of food systems: Kosher, Christian and Halal,” Br. Food J., vol. 117, no. 9, pp. 2313-2327, 2015, doi: 10.1108/BFJ-02-20150058 .

[68] R. Eid and H. El-Gohary, "The role of Islamic religiosity on the relationship between perceived value and tourist satisfaction," Tour. Manag., vol. 46, pp. 477-488, 2015, doi: 10.1016/j.tourman.2014.08.003.

[69] M. F. Sukiman, S. I. Omar, M. Muhibudin, I. Yussof, and B. Mohamed, "Tourist Satisfaction as the Key to Destination Survival in Pahang," Procedia - Soc. Behav. Sci., vol. 91, pp. 78-87, 2013, doi: 10.1016/j.sbspro.2013.08.404.

[70] H. Whang, S. Yong, and E. Ko, "Pop culture, destination images, and visit intentions: Theory and research on travel motivations of Chinese and Russian tourists," J. Bus. Res., vol. 69, no. 2, pp. 631-641, 2016, doi: 10.1016/j.jbusres.2015.06.020.

[71] S. Jang, B. Bai, C. Hu, and C. M. E. Wu, "Affect, travel motivation, and travel intention: A senior market," J. Hosp. Tour. Res., vol. 33, no. 1, pp. 51-73, 2009, doi: 10.1177/1096348008329666.

[72] C. Swee Ting, L. Khong Chiu, and K. Kayat, "Travel Lifestyles and Outbound Tourism Intentions of Young Malaysians," Am. J. Tour. Manag., vol. 2015, no. 2, pp. 40-42, 2015, doi: 10.5923/j.tourism.20150402.03.

[73] A. Mohsin, J. Lengler, and P. Chaya, "Does travel interest mediate between motives and intention to travel? A case of young Asian travellers," J. Hosp. Tour. Manag., vol. 31, pp. 36-44, 2017, doi: 10.1016/j.jhtm.2016.08.003. 
[74] M. A. Camilleri, "Chapter 1 The Planning and Development of the Tourism Product," Tour. Plan. Destin. Mark., pp. 1-23, 2018, doi: 10.1108/978-1-78756-291-220181001.

[75] B. Seetanah, V. Teeroovengadum, and R. S. Nunkoo, "Destination Satisfaction and Revisit Intention of Tourists: Does the Quality of Airport Services Matter?," J. Hosp. Tour. Res., vol. XX, no. X, pp. 1-15, 2018, doi: 10.1177/1096348018798446.

[76] U. Basaran, "Examining the Relationships of Cognitive, Affective, and Conative Destination Image: A Research on Safranbolu, Turkey," Int. Bus. Res., vol. 9, no. 5, p. 164, 2016, doi: 10.5539/ibr.v9n5p164.

[77] Y. C. Chen, R. A. Shang, and M. J. Li, "The effects of perceived relevance of travel blogs' content on the behavioral intention to visit a tourist destination," Comput. Human Behav., vol. 30, pp. 787-799, 2014, doi: 10.1016/j.chb.2013.05.019.

[78] N. Popichit, J. Anuwichanont, J. Chuanchom, S. Serirat, and P. Mechinda, "A Survey of Destination Potential, Tourism Activities and Future Travelling Intention towards Tourism along the Rivers in Phra Nakhon Si Ayutthaya Province," Int. J. Bus. Soc. Sci., vol. 4, no. 7, pp. 116-122, 2013.

[79] M. J. Khan, S. Chelliah, and S. Ahmed, "Factors influencing destination image and visit intention among young women travellers: role of travel motivation, perceived risks, and travel constraints," Asia Pacific J. Tour. Res., vol. 22, no. 11, pp. 1139-1155, 2017, doi: 10.1080/10941665.2017.1374985.

[80] M. R. Jalilvand, A. Ebrahimi, and N. Samiei, "Electronic Word of Mouth Effects on Tourists' Attitudes Toward Islamic Destinations and Travel Intention: An Empirical Study in Iran," Procedia - Soc. Behav. Sci., vol. 81, no. 2006, pp. 484-489, 2013, doi: 10.1016/j.sbspro.2013.06.465.

[81] P. Wang, "Exploring the influence of electronic word-of-mouth on tourists' visit intention: A dual process approach," J. Syst. Inf. Technol., vol. 17, no. 4, pp. 381-395, 2015, doi: 10.1108/JSIT-04-2015-0027.

[82] M. Fakharyan, "The influence of online word of mouth communications on tourists' attitudes toward Islamic destinations and travel intention: Evidence from Iran," African J. Bus. Manag., vol. 6, no. 33, pp. 10381-10388, 2012, doi: 10.5897/ajbm12.628.

[83] L. Di Pietro and E. Pantano, "Social network influences on young tourists: An exploratory analysis of determinants of the purchasing intention," J. Direct, Data Digit. Mark. Pract., vol. 15, no. 1, pp. 4-19, 2013, doi: 10.1057/dddmp.2013.33.

[84] A. M. Abubakar and M. Ilkan, "Impact of online WOM on destination trust and intention to travel: A medical tourism perspective," J. Destin. Mark. Manag., vol. 5, no. 3, pp. 192-201, 2016, doi: 10.1016/j.jdmm.2015.12.005.

[85] D. Hariani, M. Rahmanita, and R. Ingkadijaya, "The Influence of Availability of Muslim Friendly Facilities towards Indonesian Muslim Tourist Revisit Intention to Japan,” TRJ Tour. Res. J., vol. 1, no. 1, p. 133, 2017, doi: 10.30647/trj.v1i1.13.

[86] H. Han, A. Al-Ansi, and H. C. Kim, "Perceived inconveniences and Muslim travelers' loyalty to non-Muslim destinations," Sustain., vol. 11, no. 17, pp. 1-14, 2019, doi: $10.3390 /$ su11174600.

[87] M. Alderighi, C. Bianchi, and E. Lorenzini, "The impact of local food specialities on the decision to (re)visit a tourist destination: Market-expanding or business-stealing?," Tour. Manag., vol. 57, pp. 323-333, 2016, doi: 10.1016/j.tourman.2016.06.016.

[88] Sugiyono, Metode Penelitian: Kuantitatif, Kualitatif, dan R\&D. Bandung: Alfabeta, 2016. 